This document is the accepted manuscript version of the following article: Friis, E. M., Crane, P. R., Pedersen, K. R., Stampanoni, M., \& Marone, F. (2015). Exceptional preservation of tiny embryos documents seed dormancy in early angiosperms. Nature, 528, 551-554. https://doi.org/10.1038/nature16441

\title{
Exceptional preservation of tiny embryos documents seed dormancy in early angiosperms
}

\section{ELSE MARIE FRIIS ${ }^{1,2}$, PETER R. CRANE ${ }^{2}$, KAJ RAUNSGAARD PEDERSEN ${ }^{2,3}$, MARCO STAMPANONI ${ }^{4,5}$ \& FEDERICA MARONE ${ }^{4}$}

${ }^{1}$ Department of Palaeobiology, Swedish Museum of Natural History, SE-104 05 Stockholm, Sweden. ${ }^{2}$ Yale School of Forestry and Environmental Studies 195 Prospect Street, New Haven, CT 06511, USA. ${ }^{3}$ Department of Earth Science, University of Aarhus, DK-8000 Aarhus, Denmark. ${ }^{4}$ Swiss Light Source, Paul Scherrer Institute, CH-5232 Villigen PSI, Switzerland. ${ }^{5}$ Institute for Biomedical Engineering, ETZ F 85, Swiss Federal Institute of Technology Zurich, Gloriastrasse 35, 8092 Zurich, Switzerland.

The rapid diversification of angiosperms through the Early Cretaceous, between about 130 and 100 million years ago initiated fundamental changes in the composition of terrestrial vegetation and is increasingly well-understood based on a wealth of palaeobotanical discoveries over the last four decades ${ }^{1-5}$, and their integration with improved knowledge of living angiosperms ${ }^{3,6}$. Prevailing hypotheses, based on evidence from both living and fossil plants, emphasize that the earliest angiosperms were plants of small stature ${ }^{7-12}$ with rapid life cycles $^{7,8,12,13}$ that exploited disturbed habitats $3,9,11,13,14$ in open ${ }^{3,9,11,13,14}$, or perhaps understory conditions $^{15,16}$. However, direct palaeontogical data relevant to understanding the seed biology and germination ecology of Early Cretaceous angiosperms are sparse. Here we report the discovery of embryos and their associated nutrient storage tissues in exceptionally wellpreserved angiosperm seeds from the Early Cretaceous. Synchrotron radiation X-ray tomographic microscopy (SRXTM) of the fossil embryos from many taxa reveals that all were tiny at the time of dispersal. These results support hypotheses based on extant plants that tiny embryos and seed dormancy are basic for angiosperms as a whole ${ }^{17,18}$. The minute size of the fossil embryos, and the modest nutrient storage tissues dictated by the overall small seed size, is also consistent with the interpretation that many early angiosperms were opportunistic, early successional colonizers of disturbance-prone habitats ${ }^{2,15,16}$.

As part of a broader survey of Early Cretaceous angiosperm reproductive structures using SRXTM ${ }^{19}$ we analysed the internal structure of mature seeds from about 75 different angiosperm taxa recovered from rich assemblages of angiosperm flowers, fruits and seeds in 11 mesofossil floras from eastern North America and Portugal that range in age from 
Barremian-Aptian to early or middle Albian, ca. 125-110 million years ago ${ }^{3}$ (see Methods). SRXTM revealed exquisite preservation of three-dimensional cellular structure, often including traces of nuclei and subcellular nutritive bodies. In mature fossil fruits and seeds, the seed coat is generally well-developed and cellular preservation is usually excellent. Softer tissues such as embryo and nutrient storage tissues may be degraded or distorted, but of the roughly 250 Early Cretaceous mature seeds examined about half show cellular structure inside the seed coat (Supplementary Table 1). Often only the nutrient storage tissue is preserved, with an empty space at the micropylar end of the seed indicating the maximum size, and former position of the embryo and its immediately surrounding cells. In about 50 seeds complete or partially preserved embryos occur along with remains of the surrounding nutrient storage tissue. Minimal shrinkage of the seeds during preservation is indicated by the typically straight cell walls and the fact that the nutrient storage tissue often fills out the whole seed volume inside the seed coat.

All Early Cretaceous angiosperm seeds studied here are small $(<2.5 \mathrm{~mm}$ in maximum dimension ${ }^{20}$ ), and in all the fossil seeds in which it can be observed the embryo is tiny. Some embryos have two small cotyledon primordia; in others the cotyledons are not clearly differentiated. None have fully developed cotyledons or a radicle. All were preserved during a dormant phase in their development. Further growth of the embryo inside the seed would be required prior to germination.

Here we illustrate six different fossils that are representative of the diversity of embryo structure seen among all the specimens studied (Figs 1-3). Three of these fossils can be assigned to extinct genera (Anacostia, Appomattoxia, Canrightiopsis) that have already been described and assessed systematically ${ }^{3,21}$. The three other taxa (Taxon 1, 2 and 3) remain to be described and formally named. Taxon 1 and Taxon 3 are isolated exotestal seeds. Taxon 2 is a small, thin-walled seed enclosed in a one-seeded fruiting unit.

In all six kinds of seeds, the tiny embryo is surrounded by nutrient storage tissue that occupies the bulk of the space inside the seed coat (Figs 2a and 3), but the size and form of the embryo varies. The cotyledons are not clearly differentiated in Taxon 3, and in Canrightiopsis and Taxon 1 they are rudimentary. In the other three taxa cotyledon primordia are larger. Canrightiopsis has the smallest embryo (ca. $120 \mu \mathrm{m}$ long) and Appomattoxia the largest (ca. $296 \mu \mathrm{m}$ long). The embryos of Anacostia, Taxon 1, and Taxon 2 are intermediate in size (Anacostia ca. $240 \mu \mathrm{m}$ long; Taxon 1 ca. $250 \mu \mathrm{m}$ long; Taxon 2 ca. $240 \mu \mathrm{m}$ long). The embryo in Taxon 3 is distinct in being wider than long (ca. $250 \mu$ m wide; $160 \mu \mathrm{m}$ long). In all 
seeds examined the embryo size relative to the seed size (E:S; 2D area, see Methods) is very small, ranging from 0.015 in Taxon 1 to 0.034 in Anacostia.

Cellular preservation of the embryos in all six taxa is excellent. Cells are small, rectangular, often elongated parallel to the longitudinal axis and vary in length from 10-20 $\mu \mathrm{m}$. In each cell there is typically a central body about 4-6 $\mu \mathrm{m}$ in diameter (Fig. 2b) that is similar in size and position to the nuclei seen in the embryo cells of extant early diverging angiosperm lineages. The nutrient storage tissue consists of cells that range from about 40 to $70 \mu \mathrm{m}$ in diameter and have thin, usually straight, walls. Cells in the nutritive storage tissue often contain small rounded structures (Figs 2a, c and 3) that are most likely remains of the protein and lipid bodies that occur in the equivalent seed tissues of many extant angiosperms.

The nutrient storage tissue immediately around the embryo is often partly or fully decomposed, but in seeds with particularly good preservation, these cells are usually distinguished by their smaller size, thinner walls and lack of nutritive bodies. Very similar cellular differentiation occurs in the endosperm of modern Sarcandra (Fig. 4a, c) and other extant early diverging angiosperm lineages ${ }^{22-26}$. As in extant taxa the contents of the cells immediately around the embryo were apparently consumed very early in the development of the young plant.

Taxon 1 (Fig. 1a, b), Taxon 3 (Fig. 3) and Canrightiopsis (Fig. 1c-e) all have rudimentary or poorly differentiated embryos, as occur in early diverging lineages of living angiosperms (Amborellaceae, Austrobaileyaceae, Schisandraceae, Nymphaeaceae and Chloranthaceae $)^{22-26}$, as well as in some eumagnoliids ${ }^{18}$. The distinctive exotestal seeds of Taxon 1 and Taxon 3 are also indicative of a relationship to Schisandraceae or Nymphaeaceae, and the broad embryo of Taxon 3 is very similar to the embryos in seeds of extant Nymphaeaceae ${ }^{26}$.

Canrightiopsis is phylogenetically close to the common ancestor of extant Ascarina, Sarcandra and Chloranthus (Chloranthaceae) ${ }^{21}$. Comparison of the almost spherical Canrightiopsis embryo with that of extant Sarcandra shows strong similarities and the same cellular features. However, the seeds and embryos of Canrightiopsis are much smaller. In Canrightiopsis the length of the embryo is ca. $120 \mu \mathrm{m}$ (Fig. 1d, e) whereas in the specimen of extant Sarcandra illustrated here it is ca. $470 \mu \mathrm{m}$ (Fig. 4b). Endosperm and perisperm may be difficult to distinguish in mature seeds, but in this case comparison with extant Sarcandra strongly suggests that the nutrient storage tissue preserved in Canrightiopsis is endosperm.

Anacostia (Fig. 1f, g) and Appomattoxia (Fig. 1h, i) are particularly similar in embryo shape and size. Along with Taxon 2 (Fig. 1j, k) they have minute embryos with more distinct 
cotyledons ("underdeveloped linear”27). Embryos of this kind are characteristic of certain lineages among Austrobaileyales ${ }^{23,24}$, eumagnoliids and early diverging eudicots (e.g., Ranunculales, Trochodendrales) ${ }^{18}$. Anacostia and Appomattoxia both have abundant monoaperturate pollen on the stigmatic surfaces of their fruits ${ }^{3}$ making a relationship to eudicots unlikely. Pollen grains of Anacostia suggest a relationship to monocots, while other features indicate a position close to Schisandraceae ${ }^{3,6}$. Appomattoxia has features suggesting a relationship to extant Piperales ${ }^{28}$. In both cases, the minute dicotyledonous embryos are unlike those of the proposed modern relatives, adding further uncertainty to understanding the relationships of these extinct taxa.

Information on the embryos and provisioning of angiosperm seeds from the Early Cretaceous provides new data for assessing their relationships, but also contributes significantly to knowledge of the biology and ecology of early angiosperms. Seed size, based on the new material examined here, and previous work, is invariably small ${ }^{20,29}$, as expected from the small stature documented for some Early Cretaceous angiosperms ${ }^{5,9,12}$ and consistent with the strong relationship between small seed size and small stature seen among living plants $^{30}$. However, in addition, none of the Early Cretaceous seeds studied here have fully developed embryos at the time of dispersal. In all cases the embryos are minute and the embryo to seed ratio (E:S) is much smaller than occurs in most extant angiosperms. It is also smaller than the E:S ratio hypothesized for the ancestral angiosperm embryo ( $\mathrm{E}: \mathrm{S}$ of $0.16^{17}$ ) by an order of magnitude, emphasizing the additional diversity of extinct taxa close to the base of the angiosperm phylogenetic tree, and the limitations of inferring ancestral characteristics solely by extrapolation from the features of extant taxa.

Seed dormancy associated with the minute fossil embryos ensured that the seeds of early angiosperms could survive until conditions for germination and seedling establishment were favourable. However, the tiny embryo size and modest nutrient reserves were also an intrinsic developmental constraint on the rapidity with which early angiosperms could germinate in response to short-lived moisture availability. Early angiosperms would have been unable to match the very rapid germination of many angiosperms that evolved later and ultimately proved even more effective in exploiting ephemeral ecological opportunities.

Online Content Methods, along with any additional Extended Data display items and Source Data, are available in the online version of the paper; references unique to these sections appear only in the online paper. 


\section{Received ; accepted .}

1 Hughes, N. F. The Enigma of Angiosperm Origins. (Cambridge University Press, 1994).

2 Doyle, J. A. \& Hickey, L. J. in Origin and Early Evolution of Angiosperms (ed C.B. Beck) 139-206 (Columbia University Press, 1976).

3 Friis, E. M., Crane, P. R. \& Pedersen, K. R. Early Flowers and Angiosperm Evolution. (Cambridge University Press, 2011).

4 Dilcher, D. L. Early angiosperm reproduction: an introductory report. Rev. Palaeobot. Palynol. 27, 291-328 (1979).

5 Sun, G. et al. Archaefructaceae, a new basal angiosperm family. Science 296, 899-904 (2002).

6 Doyle, J. A. \& Endress, P. K. Integrating Early Cretaceous fossils into the phylogeny of living angiosperms: Magnoliidae and eudicots. J. Syst. Evol. 48, 1-35 (2010).

7 Stebbins, G. L. The probable growth habit of the earliest flowering plants. Ann. Missouri Bot. Gard. 52, 457-468 (1965).

8 Stebbins, G. L. in Origin and Early Evolution of Angiosperms (ed C.B. Beck) 300 - 311 (Columbia University Press, 1976).

9 Taylor, D. W. \& Hickey, L. J. in Flowering Plant Origin, Evolution and Phylogeny (eds D.W. Taylor \& L.J. Hickey) 232-266 (Chapman \& Hall, 1996).

10 Wing, S. L. \& Boucher, L. D. Ecological aspects of the Cretaceous flowering plant radiation. Annu. Rev Earth Planet. Sci 26, 379-421 (1998).

11 Friis, E. M., Pedersen, K. R. \& Crane, P. R. Diversity in obscurity: fossil flowers and the early history of angiosperms. Phil. Trans. R. Soc. B 365, 369-382 (2010).

12 Jud, N. A. Fossil evidence for a herbaceous diversification of early eudicot angiosperms during the Early Cretaceous. Proc. R. Soc. B 282, doi:http://dx.doi.org/10.1098/rspb.2015.1045 (2015).

13 Royer, D. L., Miller, I. M., Peppe, D. J. \& Hickey, L. J. Leaf economic traits from fossils support a weedy habit for early angiosperms. Am. J. Bot. 97, 438-445, doi:10.3732/ajb.0900290 (2010).

14 Taylor, D. W. \& Hickey, L. J. An Aptian plant with attached leaves and flowers: Implications for angiosperms origin. Science 247, $702-704$ (1990).

15 Feild, T. S., Arens, A. C., Doyle, J. A., Dawson, T. E. \& Donoghue, M. J. Dark and disturbed: a new image of early angiosperm ecology. Paleobiology 30, 82-107 (2004).

16 Lee, A. P., Upchurch Jr., G., Murchie, E. H. \& Lomax, B. H. Leaf energy balance modelling as a tool to infer habitat preference in the early angiosperms. Proc. R. Soc. B 282: 20143052, doi:http://dx.doi.org/10.1098/rspb.2014.3052 (2015).

17 Forbis, T. A., Floyd, S. K. \& de Queiroz, A. The evolution of embryo size in angiosperms and other seed plants: implications for the evolution of seed dormancy. Evolution 56, 2112-2125 (2002).

18 Baskin, C. C. \& Baskin, J. M. Seeds, Ecology, Biogeography, and Evolution of Dormancy and Germination. 2 edn, 1-1586 (Academic Press, 2014).

19 Friis, E. M., Marone, F., Pedersen, K. R., Crane, P. R. \& Stampanoni, M. Three-dimensional visualization of fossil flowers, fruits, seeds and other plant remains using synchrotron radiation X-ray tomographic microscopy (SRXTM): New insights into Cretaceous plant diversity. J. Paleontol. 88, 684-701, doi:10.1.1666/13-099 (2014).

20 Eriksson, O., Friis, E. M., Pedersen, K. R. \& Crane, P. R. Seed size and dispersal systems of Early Cretaceous angiosperms from Famalicão, Portugal. Int. J. Plant. Sci. 161, 319-329 (2000).

21 Friis, E. M., Grimm, G. W., Mendes, M. M. \& Pedersen, K. R. Canrightiopsis, a new Early Cretaceous fossil with Clavatipollenites-type pollen bridge the gap between extinct Canrightia and extant Chloranthaceae. Grana 54, 184-212 (2015).

22 Floyd, S. K. \& Friedman, W. E. Evolution of endosperm developmental patterns among basal flowering plants. Int. J. Plant. Sci. 161, S57-S81 (2000). 
23 Friedman, W. E. \& Bachelier, J. B. Seed development in Trimenia (Trimeniaceae) and its bearing on the evolution of embryo-nourishing strategies in early flowering plant Am. J. Bot. 100, 906-915 (2013).

24 Floyd, S. K. \& Friedman, W. E. Developmental evolution of endosperm in basal angiosperms: Evidence from Amborella (Amborellaceae), Nuphar (Nymphaeaceae), and Illicium (Illiciaceae). Pl. Syst. Evol, 228, 153 - 169 (2001).

25 Tobe, H., Jaffre, T. \& Raven, P. H. Embryology of Amborella (Amborellaceae): descriptions and polarity of character states. J. Plant Res. 113, 271-280 (2000).

26 Povilus R.A., Losada, J.M., Friedman, W.E. Floral biology and ovule and seed ontogeny of Nymphaea thermarum, a water lily at the brink of extinction with potential as a model system for basal angiosperms. Ann. Bot. 115: 211-226 (2015).

27 Baskin, C. C. \& Baskin, J. M. A revision of Martin's seed classication system, with particular reference to his dwarf-seed type. Seed Sci. Res. 17, 11-20 (2007).

28 Friis, E. M., Pedersen, K. R. \& Crane, P. R. Appomattoxia ancistrophora gen. et sp. nov., a new Early Cretaceous plant with similarities to Circaeaster and extant Magnoliidae. Am. J. Bot. 82, 933-943 (1995).

29 Eriksson, O., Friis, E. M. \& Löfgren, P. Seed size, fruit size and dispersal spectra in angiosperms from the Early Cretaceous to the Late Tertiary. Am. Nat. 156, 47-58 (2000).

30 Moles, A. T. et al. A brief history of seed size. Science 307, 576-580 (2005).

Supplementary Information is available in the online version of the paper.

Acknowledgements We thank Anna Lindström for assistance with the SRXTM analyses.

Research reported here was supported by the Swedish Natural Science Research Foundation, the Edward P. Bass Distinguished Visiting Fellowship and by the European Community's Seventh Framework Programme (FP7/2007-2013) under grant agreement n. 312284 (for CALIPSO) for the SRXTM analyses at the SLS.

Author Contributions E.M.F., K.R.P. and P.R.C. collected and prepared the fossil material for analyses. The measurements and reconstructions were performed by E.M.F. F.M and M.S. developed the algorithms for the analyses and enhanced the measurements. The paper was prepared by the authors jointly.

Author Information Reprints and permissions information is available at

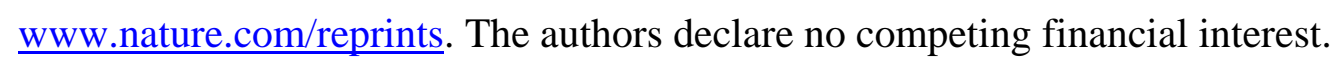
Correspondence and requests should be addressed to E.M.F (else.marie.friis@nrm.se).

Text to figures:

Figure 1 Minute embryos with two cotyledon primordia in Early Cretaceous angiosperms. SRXTM reconstructions of embryos embedded in seeds (a, c, f, h, j) and 
isolated from seeds (b, d, e, g, i, k). a, b, Exotestal seed and embryo (Taxon 1; S170235, Famalicão). c-e, Canrightiopsis with seed and embryo (S174005, Famalicão). f, g, Anacostia fruit with seed and embryo (PP54021, Kenilworth). h, i, Appomattoxia with seed and embryo (PP54064, Puddledock). j, k, Fruit with seed and embryo (Taxon 2; PP53991, Kenilworth). Scale bars, $500 \mu \mathrm{m}$ (a, c, f, h, j), $100 \mu \mathrm{m}$ (b, d, e, g, i, k).

\section{Figure 2 Cellular preservation of embryos and associated nutrient storage tissue in} Early Cretaceous angiosperm seeds. Longitudinal orthoslices through SRXTM volumes. a, Apical part of fruit in figure $\mathbf{1 j}$ (Taxon 2) showing embryo and surrounding storage tissue with remains of nutritive bodies (arrow). b, Detail of embryo in 2a showing the cotyledon primordia (asterisks) and embryo cells with a central body that may represent remains of the nucleus; thin-walled storage tissue is preserved between the cotyledons. c, Details of nutrient storage tissue from an Early Cretaceous exotestal seed (PP53973, Puddledock) with remains of nutritive bodies (arrow). Scale bars, $100 \mu \mathrm{m}$.

\section{Figure 3 Minute and broad embryo and associated nutrient storage tissue in an Early} Cretaceous seed (Taxon 3). Longitudinal 2D SRXTM reconstructions of micropylar region of exotesal seed (S174472, Famalicão 25) showing the broad shape and poorly differentiated embryo (arrow). a, Cut volume rendering (between orthoslices 1380-1420) coloured to emphasize the shape and position of embryo. b, Single orthoslice (orthoslice 1420) in same position as in 3a. Scale bars, $100 \mu \mathrm{m}$.

Figure 4 Embryo and nutrient storage tissue of extant Sarcandra (Chloranthaceae). 2D (a, c) and 3D (b) SRXTM reconstructions. a, Longitudinal orthoslice through seed showing rudimentary embryo with two cotyledon primordia (asterisks) embedded in copious nutrient storage tissue (endosperm); cells in the vicinity of the embryo lack the nutritive bodies that are abundant in other endosperm cells. b, Surface rendering of embryo showing the two small cotyledon primordia. c, Detail of endosperm with nutritive bodies (protein and lipids). Scale bars, $100 \mu \mathrm{m}$. 


\section{Methods}

The fossil seeds studied here were isolated from 11 mesofossil floras preserved in soft unconsolidated sediments from eastern North America (Kenilworth, Maryland; Dutch Gap and Puddledock, Virginia) and Portugal (Arazede, Buarcos, Catefica, Famalicão, JuncalChicalhão, Torres Vedras, Vale de Água, Vila Verde) that range from Barremian-Aptian to early or middle Albian in age $\mathrm{3}^{3,21,28,31}$. Mesofossils preserved in these floras are often exquisitely preserved in three dimensions as charcoalified or lignitic specimens and include complete and fragmentary flowers, as well as abundant fruits and seeds. Fossils were isolated from the sediments by sieving in water, remaining mineral matrix was removed using HF and $\mathrm{HCl}$, and the fossils were then rinsed in water and air-dried. A large number of specimens of mature seeds, from the full range of taxa preserved, were analysed using synchrotron radiation X-ray tomographic microscopy (SRXTM). Six fossils representative of the material examined were selected to illustrate common features of embryos and nutritive storage tissues. Specimens examined with SRXTM were mounted on brass-stubs with nail polish and analysed at the TOMCAT beamline ${ }^{32}$ at the Swiss Light Source, Villigen, Switzerland. For optimized contrast, measurements were made at $10 \mathrm{keV}$. For each data set, 1501 projections equiangularly spaced over 180 degrees were acquired. The transmitted and refracted X-ray radiation was converted to visible light by a thin scintillating screen (20 $\mu \mathrm{m}$ thick LAG:Ce or $5.9 \mu \mathrm{m}$ thick LSO:Tb depending on the spatial resolution required), magnified by $\times 10$ and $\times 20$ objective lenses for overviews, and $\times 40$ objective lens for details, and digitized by a CCD (PCO.2000) or a sCMOS (PCO.edge) camera. The sample-detector distance was on the order of few mm. The raw projections were dark and flat-field corrected and subsequently reconstructed using an efficient algorithm based on the Fourier method with regridding ${ }^{33}$. The resulting volumetric data have voxel sizes of $0.65-0.74,0.325$ and $0.1625 \mu \mathrm{m}$, for measurements done with the x10, x20 and x40 objectives respectively.

To boost contrast in the detailed scan of specimen PP53991 (Fig. 2b and 2c), prior to tomographic reconstruction, the corrected projections were phase retrieved according to the single distance algorithm by Paganin et al. ${ }^{34}$.

Embryo tissue was identified in the reconstructed SRXTM orthoslices and Avizo software was used to manually label individual slices to generate the three-dimensional embryo shapes. To illustrate the relationship of seed and embryo volume, the embryo surface was coloured yellow and the three-dimensional shape of the seeds/fruits shown by transparent voltex rendering in green (Fig. 1). The 2D area of embryo and seed inside the integuments 
was measured in pixels on longitudinal sections through the middle of the seeds and embryos using the free software Fiji ${ }^{35}$ resulting in an embryo to seed ratio (E:S) comparable to that published by others ${ }^{17}$.

A list of the mature seeds analysed here is available in Supplementary Table 1. The fossil material is stored in the palaeobotanical collections of the Swedish Museum of Natural History, Stockholm (S) and the Field Museum, Chicago (PP). Raw data from the SRXTM are stored at the Swedish Museum of Natural History.

31 Friis, E. M., Crane, P. R. \& Pedersen, K. R. Anacostia, a new basal angiosperm from the Early Cretaceous of North America and Portugal with monocolpate/trichotomocolpate pollen. Grana 36, 225-244 (1997).

32 Stampanoni, M. et al. in Developments in X-Ray Tomography V Vol. 6318 (ed U. Bonse) (Proceedings of SPIE-The International Society for Optical Engineering, 2006).

33 Marone, F. \& Stampanoni, M. Regridding reconstruction algorithm for real-time tomographic imaging. J. Synchrotron Rad. 19, 1029-1037 (2012).

34 Paganin, D., Mayo, S. C., Gureyev, T. E., Miller, P. R. \& Wilkins, S. W. Simultaneous phase and amplitude extraction from a single defocused image of a homogeneous object. J. Microsc. (Oxf.) 206, 33-40 (2002).

35 Schindelin, J. et al. Fiji: an open-source platform for biological-image analysis. Nature methods 9, 676-682, doi:doi:10.1038/nmeth.2019 (2012). 


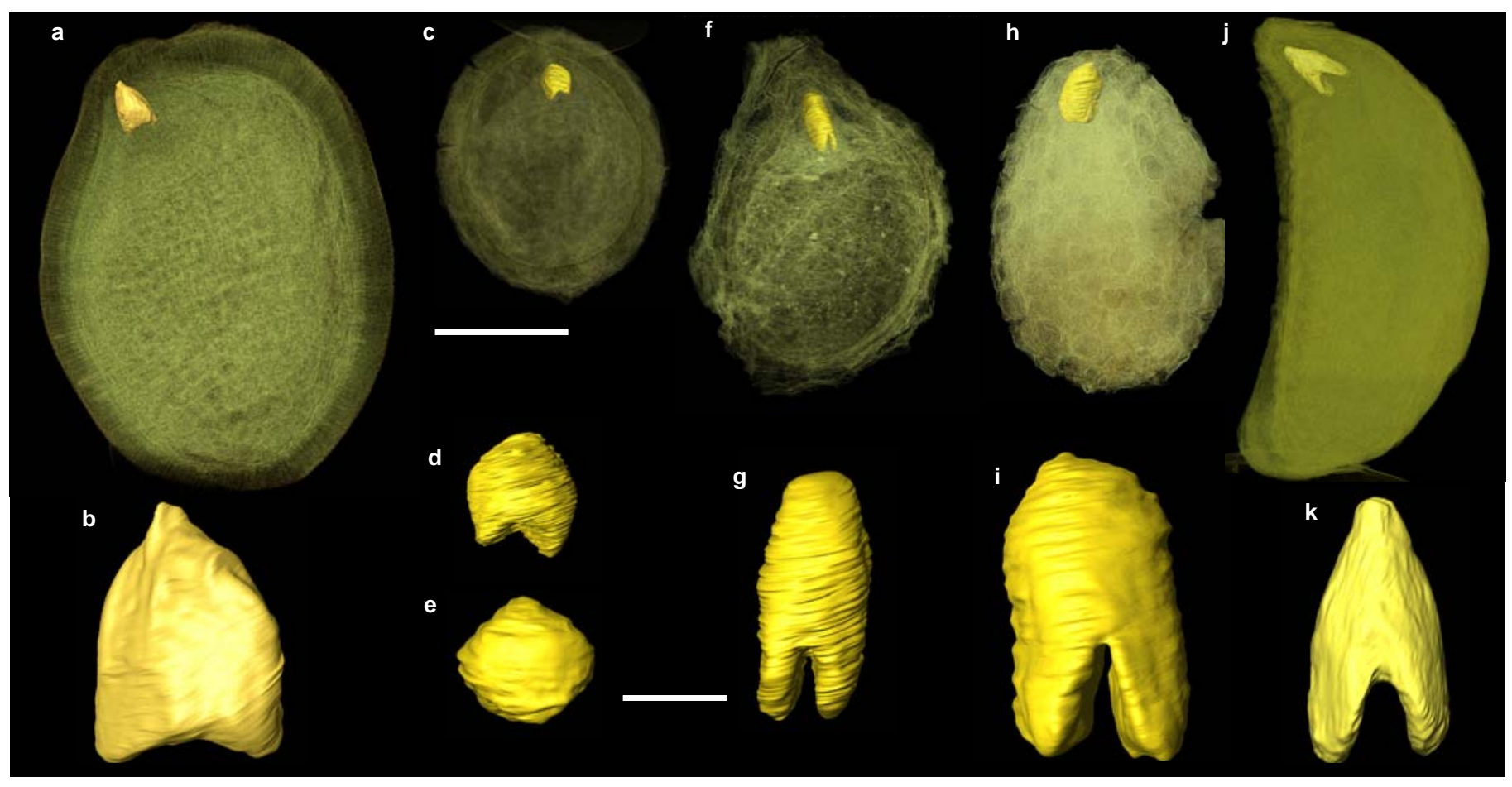




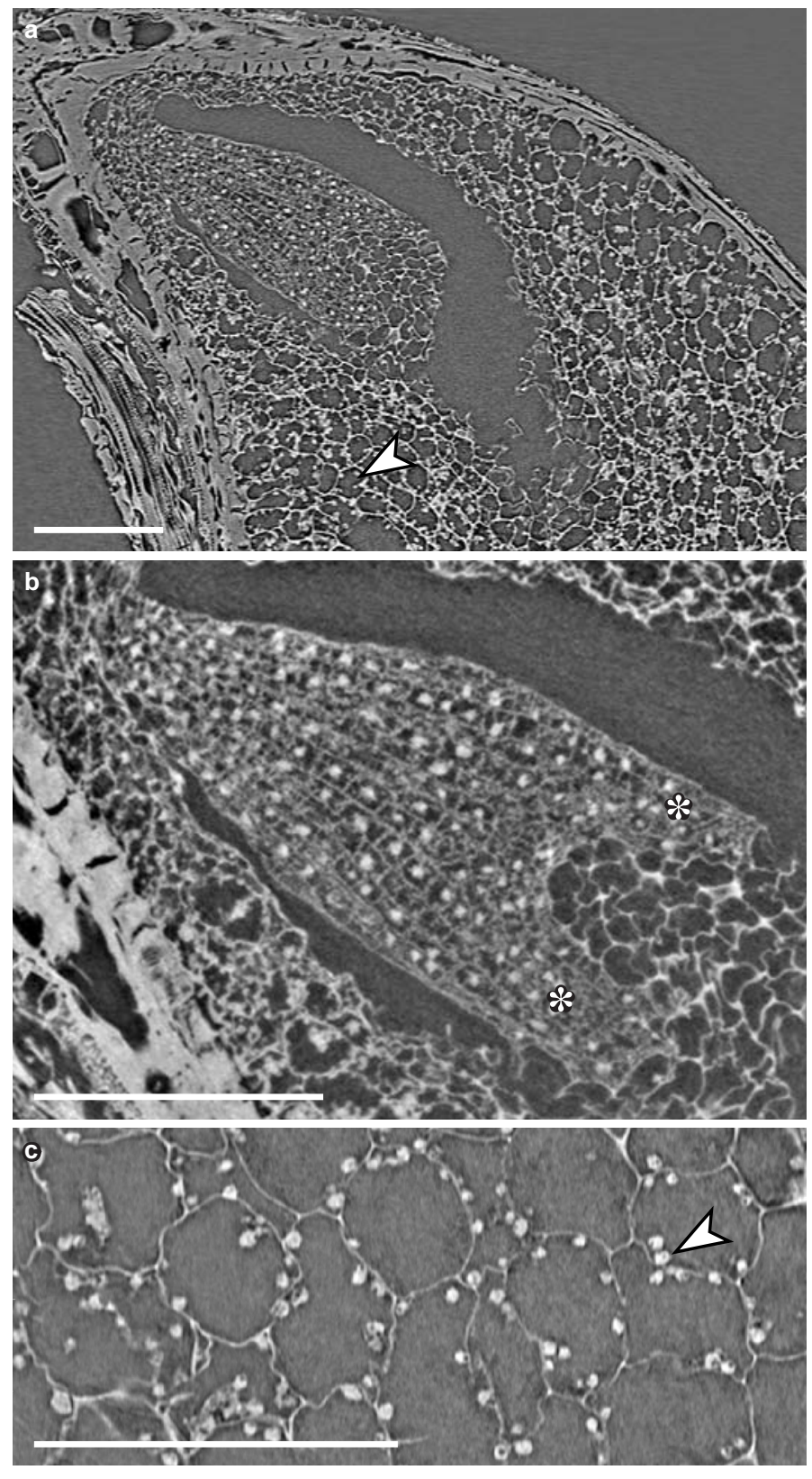




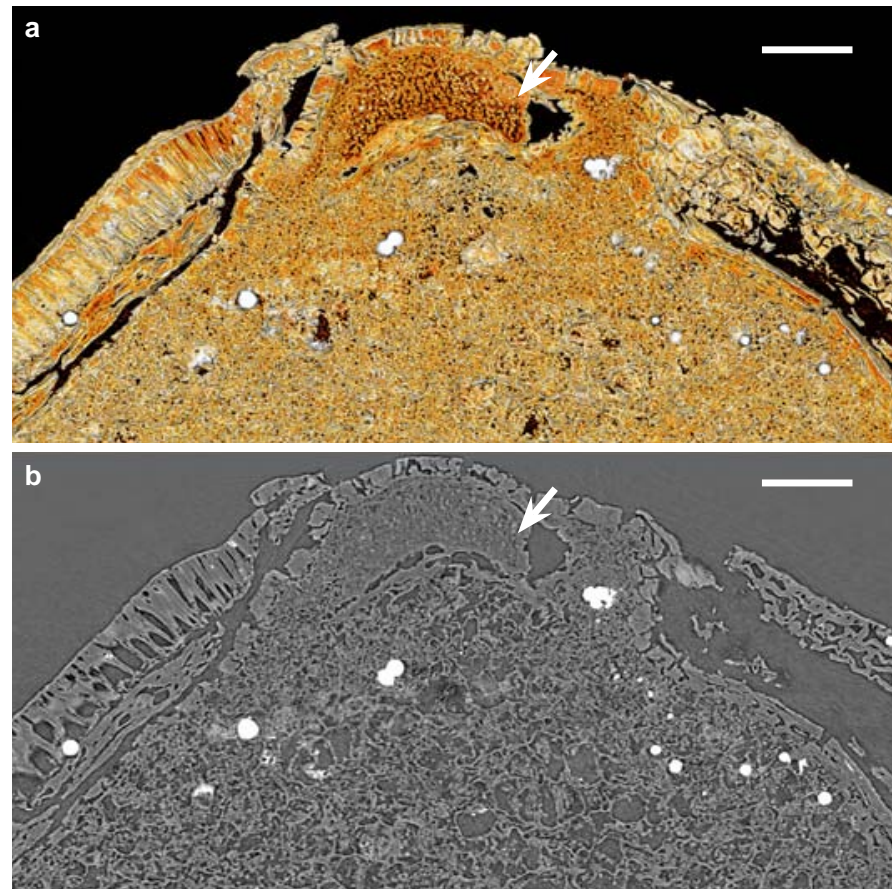




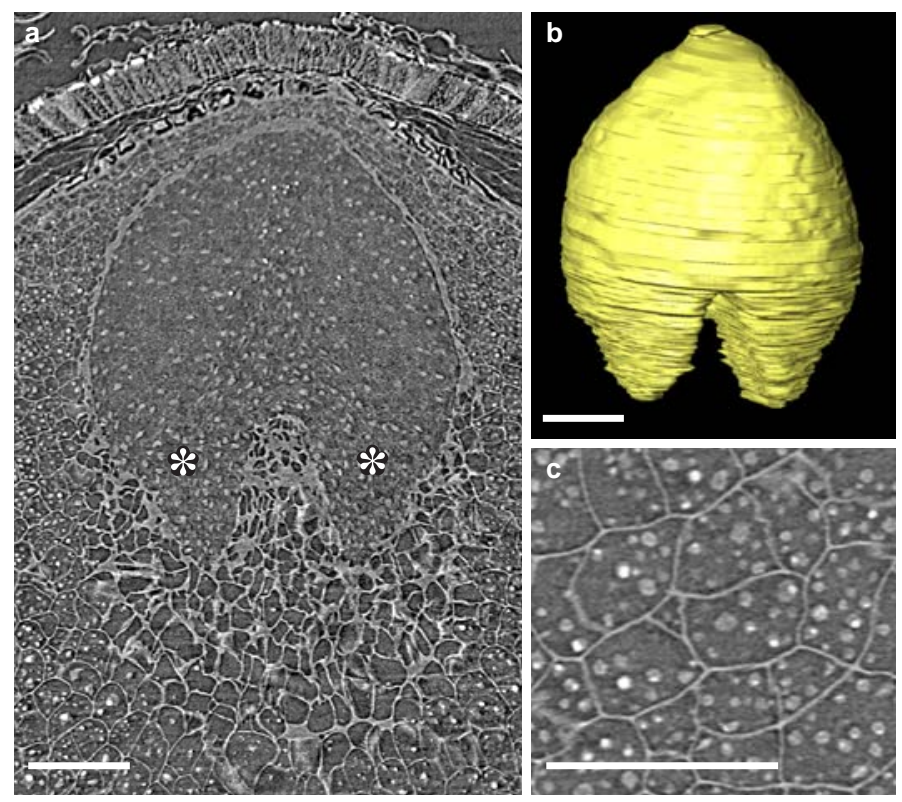


Supplementary Table 1 I List of Early Cretaceous fruits with mature seeds and isolated, mature seeds studied using SRXTM. Currently undescribed seeds are here grouped into informal taxa numbered Taxon 1, Taxon 2 etc. 
List of Early Cretaceous fruits with mature seeds and isolated, mature seeds studied using SRXTM. Currently undescribed seeds are here grouped into informal taxa numbered Taxon 1, Taxon 2 etc.

\begin{tabular}{|c|c|c|c|c|c|c|}
\hline $\begin{array}{l}\text { Specimen } \\
\text { no }\end{array}$ & Sample no & Taxon & Unit studied & Seed coat & Embryo & Nutritive storage tissue \\
\hline PP54021 & Kenilworth 061 & Anacostia marylandensis & one-seeded fruit & exotestal & embryo preserved & nutritive tissue preserved, partly \\
\hline PP54076 & Kenilworth 061 & Anacostia marylandensis & one-seeded fruit & exotestal & & seed empty \\
\hline PP54084 & Kenilworth 175 & Anacostia marylandensis & one-seeded fruit & exotestal & & seed empty \\
\hline PP54091 & Kenilworth 174 & Anacostia marylandensis & seed & exotestal & & seed empty \\
\hline PP54092 & Kenilworth 174 & Anacostia marylandensis & one-seeded fruit & exotestal & & seed empty \\
\hline PP54093 & Kenilworth 174 & Anacostia marylandensis & one-seeded fruit & exotestal & & nutritive tissue preserved, partly \\
\hline PP54094 & Kenilworth 174 & Anacostia marylandensis & one-seeded fruit & exotestal & & nutritive tissue preserved, partly \\
\hline PP54095 & Kenilworth 174 & Anacostia marylandensis & one-seeded fruit & exotestal & & nutritive tissue preserved, partly \\
\hline PP54096 & Kenilworth 174 & Anacostia marylandensis & seed & exotestal & & seed empty \\
\hline S172400 & Famalicão 25 & Anacostia sp. & seed & exotestal & & seed empty \\
\hline S172401 & Famalicão 25 & Anacostia sp. & seed & exotestal & & nutritive tissue poorly preserved \\
\hline S174031 & Famalicão 25 & Anacostia sp. & seed & exotestal & & seed empty \\
\hline S174032 & Famalicão 25 & Anacostia sp. & seed & exotestal & embryo preserved, partly & nutritive tissue preserved \\
\hline S174168 & Vale de Agua 408 & Anacostia sp. & seed & exotestal & & seed empty \\
\hline PP54042 & Puddledock 082 & Anacostia virginiensis & one-seeded fruit & exotestal & embryo preserved, partly & nutritive tissue preserved, partly \\
\hline PP54046 & Puddledock 082 & Anacostia virginiensis & one-seeded fruit & exotestal & & nutritive tissue preserved, partly \\
\hline PP54034 & Puddledock 156 & Appomattoxia ancistrophora & one-seeded fruit & seed coat thin & empty space from embryo & nutritive tissue preserved, partly \\
\hline PP54065 & Puddledock 156 & Appomattoxia ancistrophora & one-seeded fruit & seed coat thin & embryo preserved & \\
\hline PP54067 & Puddledock 156 & Appomattoxia ancistrophora & one-seeded fruit & endotestal & & nutritive tissue preserved, partly \\
\hline S153507 & Famalicão 25 & Canrightia resinifera & two-seeded fruit & endotestal & & nutritive tissue preserved, partly \\
\hline S153508 & Famalicão 25 & Canrightia resinifera & two-seeded fruit & endotestal & & nutritive tissue preserved, partly \\
\hline S170111 & Famalicão 25 & Canrightia resinifera & two-seeded fruit & endotestal & & nutritive tissue preserved, partly \\
\hline S170112 & Famalicão 25 & Canrightia resinifera & two-seeded fruit & endotestal & & seed empty \\
\hline S171506 & Catefica 50 & Canrightia resinifera & seed & endotestal & & seed empty \\
\hline S171507 & Catefica 50 & Canrightia resinifera & seed & endotestal & & seed empty \\
\hline S171508 & Catefica 50 & Canrightia resinifera & two-seeded fruit & endotestal & & seed empty \\
\hline
\end{tabular}




\begin{tabular}{|c|c|c|c|c|c|c|}
\hline S171509 & Catefica 50 & Canrightia resinifera & three-seeded fruit & endotestal & & seed empty \\
\hline S171510 & Famalicão 25 & Canrightia resinifera & seed & endotestal & & nutritive tissue preserved, partly \\
\hline S171511 & Famalicão 25 & Canrightia resinifera & seed & endotestal & & nutritive tissue preserved, partly \\
\hline S171512 & Famalicão 25 & Canrightia resinifera & seed & endotestal & & nutritive tissue preserved, partly \\
\hline S171513 & Famalicão 25 & Canrightia resinifera & seed & endotestal & & nutritive tissue preserved, partly \\
\hline S174008 & Catefica 50 & Canrightia resinifera & two-seeded fruit & endotestal & & seed empty \\
\hline S174312 & Catefica 153 & Canrightia resinifera & three-seeded fruit & endotestal & & seed empty \\
\hline S174100 & Torres Vedras 38 & Canrightia sp. & three-seeded fruit & endotestal & & nutritive tissue preserved, partly \\
\hline S174039 & Catefica 49 & Canrightiopsis crassitesta & one-seeded fruit & endotestal & & seed empty \\
\hline S174159 & Catefica 49 & Canrightiopsis crassitesta & one-seeded fruit & endotestal & empty space from embryo & nutritive tissue preserved, partly \\
\hline S174248 & Catefica 49 & Canrightiopsis crassitesta & one-seeded fruit & endotestal & & seed empty \\
\hline S174310 & Catefica 154 & Canrightiopsis crassitesta & one-seeded fruit & endotestal & & nutritive tissue preserved, partly \\
\hline S174311 & Catefica 343 & Canrightiopsis crassitesta & one-seeded fruit & endotestal & & seed empty \\
\hline P0311 & Juncal-Chicalhão & Canrightiopsis dinisii & one-seeded fruit & endotestal & & seed empty \\
\hline S174004 & Famalicão 25 & Canrightiopsis intermedia & one-seeded fruit & endotestal & & seed empty \\
\hline S174005 & Famalicão 25 & Canrightiopsis intermedia & one-seeded fruit & endotestal & embryo preserved & nutritive tissue preserved, partly \\
\hline S174006 & Famalicão 25 & Canrightiopsis intermedia & one-seeded fruit & endotestal & empty space from embryo & nutritive tissue preserved, partly \\
\hline S174023 & Famalicão 25 & Canrightiopsis intermedia & seed & endotestal & & seed empty \\
\hline S174024 & Famalicão 25 & Canrightiopsis intermedia & seed & endotestal & embryo preserved, poorly & nutritive tissue preserved, partly \\
\hline S174025 & Famalicão 25 & Canrightiopsis intermedia & seed & endotestal & & nutritive tissue preserved, partly \\
\hline S174026 & Famalicão 25 & Canrightiopsis intermedia & seed & endotestal & & seed empty \\
\hline S174027 & Famalicão 25 & Canrightiopsis intermedia & seed & endotestal & empty space from embryo & nutritive tissue preserved, partly \\
\hline S174028 & Famalicão 25 & Canrightiopsis intermedia & seed & endotestal & & seed empty \\
\hline S174033 & Famalicão 25 & Canrightiopsis intermedia & seed & endotestal & & nutritive tissue preserved, partly \\
\hline S174104 & Buarcos 157 & Canrightiopsis intermedia & one-seeded fruit & endotestal & & nutritive tissue preserved, partly \\
\hline S174105 & Buarcos 157 & Canrightiopsis intermedia & one-seeded fruit & endotestal & & nutritive tissue preserved, partly \\
\hline S174107 & Famalicão 25 & Canrightiopsis intermedia & one-seeded fruit & endotestal & empty space from embryo & nutritive tissue preserved, partly \\
\hline S174108 & Famalicão 25 & Canrightiopsis intermedia & one-seeded fruit & endotestal & & nutritive tissue preserved, partly \\
\hline S174148 & Famalicão 25 & Canrightiopsis intermedia & one-seeded fruit & endotestal & embryo preserved, poorly & nutritive tissue preserved, partly \\
\hline S174150 & Famalicão 25 & Canrightiopsis intermedia & one-seeded fruit & endotestal & & nutritive tissue preserved, partly \\
\hline
\end{tabular}




\begin{tabular}{|c|c|c|c|c|c|c|}
\hline S174151 & Famalicão 25 & Canrightiopsis intermedia & one-seeded fruit & endotestal & embryo preserved, poorly & nutritive tissue preserved, partly \\
\hline S174152 & Famalicão 25 & Canrightiopsis intermedia & one-seeded fruit & endotestal & embryo preserved & nutritive tissue preserved, partly \\
\hline S174153 & Famalicão 25 & Canrightiopsis intermedia & one-seeded fruit & endotestal & embryo preserved & nutritive tissue preserved, partly \\
\hline S174155 & Famalicão 25 & Canrightiopsis intermedia & one-seeded fruit & endotestal & embryo preserved & nutritive tissue preserved, partly \\
\hline S174156 & Famalicão 25 & Canrightiopsis intermedia & one-seeded fruit & endotestal & & seed empty \\
\hline S174157 & Famalicão 25 & Canrightiopsis intermedia & one-seeded fruit & endotestal & empty space from embryo & nutritive tissue preserved, partly \\
\hline S174174 & Vale de Agua 331 & Canrightiopsis intermedia & one-seeded fruit & endotestal & empty space from embryo & nutritive tissue preserved, partly \\
\hline S172333 & Catefica 153 & Canrightiopsis sp. & seed & endotestal & & nutritive tissue preserved, partly \\
\hline S174040 & Catefica 49 & Canrightiopsis sp. & one-seeded fruit & endotestal & & seed empty \\
\hline S174149 & Famalicão 25 & Canrightiopsis sp. & one-seeded fruit & endotestal & & seed empty \\
\hline S174309 & Catefica 154 & Canrightiopsis sp. & one-seeded fruit & endotestal & & seed empty \\
\hline PP53966 & Puddledock 156 & Couperites sp. & one-seeded fruit & exotestal & & seed empty \\
\hline PP53967 & Puddledock 156 & Couperites sp. & one-seeded fruit & exotestal & & seed empty \\
\hline PP53967 & Puddledock 156 & Couperites sp. & one-seeded fruit & exotestal & & strongly compressed \\
\hline PP54031 & Puddledock 156 & Couperites sp. & seed & exotestal & & seed empty \\
\hline PP54032 & Puddledock 156 & Couperites sp. & seed & exotestal & & seed empty \\
\hline PP54071 & Puddledock 156 & Couperites sp. & one-seeded fruit & exotestal & & seed empty \\
\hline PP54072 & Puddledock 156 & Couperites sp. & one-seeded fruit & exotestal & & seed empty \\
\hline S170235 & Famalicão 25 & Taxon 01 & seed & exotestal & embryo preserved & nutritive tissue preserved \\
\hline S170236 & Famalicão 25 & Taxon 01 & seed & exotestal & empty space from embryo & nutritive tissue preserved, partly \\
\hline S174034 & Famalicão 25 & Taxon 01 & seed & exotestal & & nutritive tissue preserved, partly \\
\hline S174346 & Famalicão 25 & Taxon 01 & seed & exotestal & & seed almost empty \\
\hline S174348 & Famalicão 25 & Taxon 01 & seed & exotestal & & seed empty \\
\hline S174349 & Famalicão 25 & Taxon 01 & seed & exotestal & & seed almost empty \\
\hline S174350 & Famalicão 25 & Taxon 01 & seed & exotestal & & nutritive tissue preserved, partly \\
\hline S174351 & Famalicão 25 & Taxon 01 & seed & exotestal & embryo preserved, partly & nutritive tissue preserved, partly \\
\hline S174431 & Famalicão 25 & Taxon 01 & seed & exotestal & empty space from embryo & nutritive tissue preserved, partly \\
\hline S174432 & Famalicão 25 & Taxon 01 & seed & exotestal & & seed empty \\
\hline S174433 & Famalicão 25 & Taxon 01 & seed & exotestal & & seed almost empty \\
\hline S174471 & Famalicão 25 & Taxon 01 & seed & exotestal & & seed empty \\
\hline
\end{tabular}




\begin{tabular}{|c|c|c|c|c|c|c|}
\hline S174473 & Famalicão 25 & Taxon 01 & seed & exotestal & empty space from embryo & nutritive tissue preserved, partly \\
\hline PP53991 & Puddledock 156 & Taxon 02 & one-seeded fruit & seed coat thin & embryo preserved & nutritive tissue preserved \\
\hline PP54069 & Puddledock 156 & Taxon 02 & seed & seed coat thin & embryo preserved, partly & nutritive tissue preserved, partly \\
\hline S170238 & Famalicão 25 & Taxon 03 & seed & exotestal & & nutritive tissue preserved, partly \\
\hline S170239 & Famalicão 25 & Taxon 03 & seed & exotestal & embryo preserved, partly & nutritive tissue preserved, partly \\
\hline S174035 & Famalicão 25 & Taxon 03 & seed & exotestal & empty space from embryo & nutritive tissue preserved, partly \\
\hline S174343 & Famalicão 25 & Taxon 03 & seed & exotestal & & seed empty \\
\hline S174345 & Famalicão 25 & Taxon 03 & seed & exotestal & embryo preserved, partly & nutritive tissue preserved, partly \\
\hline S174352 & Famalicão 25 & Taxon 03 & seed & exotestal & empty space from embryo & nutritive tissue preserved, partly \\
\hline S174353 & Famalicão 25 & Taxon 03 & seed & exotestal & empty space from embryo & nutritive tissue preserved, partly \\
\hline S174467 & Famalicão 25 & Taxon 03 & seed & exotestal & embryo preserved, partly & nutritive tissue preserved \\
\hline S174469 & Famalicão 25 & Taxon 03 & seed & exotestal & embryo preserved & nutritive tissue preserved \\
\hline S174470 & Famalicão 25 & Taxon 03 & seed & exotestal & embryo preserved, partly & nutritive tissue preserved \\
\hline S174472 & Famalicão 25 & Taxon 03 & seed & exotestal & embryo preserved & nutritive tissue preserved \\
\hline S174474 & Famalicão 25 & Taxon 03 & seed & exotestal & embryo preserved & nutritive tissue preserved \\
\hline S105218 & Famalicão 25 & Taxon 04 & seed & exotestal & & seed almost empty \\
\hline S170234 & Famalicão 25 & Taxon 04 & seed & exotestal & & seed empty \\
\hline S174336 & Famalicão 25 & Taxon 04 & seed & exotestal & & nutritive tissue preserved, partly \\
\hline S174354 & Famalicão 25 & Taxon 04 & seed & exotestal & empty space from embryo & nutritive tissue preserved, partly \\
\hline S174430 & Famalicão 25 & Taxon 04 & seed & exotestal & empty space from embryo & nutritive tissue preserved, partly \\
\hline S174435 & Famalicão 25 & Taxon 04 & seed & exotestal & & seed almost empty \\
\hline S174468 & Famalicão 25 & Taxon 04 & seed & exotestal & embryo preserved & nutritive tissue preserved \\
\hline S174171 & Vale de Agua 408 & Taxon 05 & seed & exotestal & & nutritive tissue preserved, partly \\
\hline S154533 & Famalicão 25 & Taxon 06 & seed & exotestal & empty space from embryo & nutritive tissue preserved, partly \\
\hline S172316 & Catefica 49 & Taxon 07 & seed & exotestal & embryo preserved, partly & nutritive tissue preserved, partly \\
\hline S170237 & Famalicão 25 & Taxon 08 & seed & exotestal & & nutritive tissue preserved, partly \\
\hline S174337 & Famalicão 25 & Taxon 08 & seed & exotestal & & seed empty \\
\hline S174338 & Famalicão 25 & Taxon 08 & seed & exotestal & empty space from embryo & nutritive tissue preserved, partly \\
\hline S174339 & Famalicão 25 & Taxon 08 & seed & exotestal & & nutritive tissue preserved, partly \\
\hline S174340 & Famalicão 25 & Taxon 08 & seed & exotestal & & seed empty \\
\hline
\end{tabular}




\begin{tabular}{|c|c|c|c|c|c|c|}
\hline S174341 & Famalicão 25 & Taxon 08 & seed & exotestal & & nutritive tissue preserved, partly \\
\hline S174347 & Famalicão 25 & Taxon 08 & seed & exotestal & & nutritive tissue preserved, partly \\
\hline S174358 & Arazede 374 & Taxon 08 & seed & exotestal & & nutritive tissue preserved, partly \\
\hline S174179 & Vale de Agua 141 & Taxon 09 & seed & exotestal & & seed empty \\
\hline S174338 & Famalicão 25 & Taxon 09 & seed & exotestal & empty space from embryo & nutritive tissue preserved \\
\hline S174036 & Vale de Agua 265 & Taxon 10 & seed & exotestal & & seed empty \\
\hline S174189 & Vale de Agua 141 & Taxon 10 & seed & exotestal & & seed empty \\
\hline S174363 & Arazede 374 & Taxon 10 & seed & exotestal & embryo preserved, partly & nutritive tissue preserved, partly \\
\hline S170110 & Famalicão 25 & Taxon 11 & seed & exotestal & & seed empty \\
\hline S170232 & Famalicão 25 & Taxon 11 & seed & exotestal & & seed empty \\
\hline S170233 & Famalicão 25 & Taxon 11 & seed & exotestal & & seed empty \\
\hline S172332 & Catefica 153 & Taxon 11 & seed & exotestal & & seed empty \\
\hline S174177 & Vale de Agua 141 & Taxon 11 & seed & exotestal & & seed empty \\
\hline S174178 & Vale de Agua 141 & Taxon 11 & seed & exotestal & empty space from embryo & nutritive tissue preserved, partly \\
\hline S174344 & Famalicão 25 & Taxon 11 & seed & exotestal & empty space from embryo & nutritive tissue preserved, partly \\
\hline S174187 & Vale de Agua 329 & Taxon 12 & one-seeded fruit & endotestal? & embryo preserved, partly & nutritive tissue preserved, partly \\
\hline S170240 & Famalicão 25 & Taxon 13 & seed & seed coat thin & embryo preserved & nutritive tissue preserved, partly \\
\hline S174424 & Famalicão 25 & Taxon 13 & seed & seed coat thin & & nutritive tissue preserved, partly \\
\hline S174425 & Famalicão 25 & Taxon 13 & seed & seed coat thin & embryo preserved & nutritive tissue preserved, partly \\
\hline S170241 & Famalicão 25 & Taxon 14 & seed & endotestal & & seed empty \\
\hline S170242 & Famalicão 25 & Taxon 14 & seed & endotestal & embryo preserved, partly & nutritive tissue preserved, partly \\
\hline S174029 & Famalicão 25 & Taxon 14 & seed & endotestal & & seed empty \\
\hline S174030 & Famalicão 25 & Taxon 14 & seed & endotestal & embryo preserved, poorly & nutritive tissue preserved, partly \\
\hline S174422 & Famalicão 25 & Taxon 14 & seed & endotestal & & seed empty \\
\hline $\begin{array}{l}\text { S170108/ } \\
\text { S174095 }\end{array}$ & Famalicão 25 & Taxon 15 & three-seeded fruit & endotestal & & seed empty \\
\hline S170109 & Famalicão 25 & Taxon 15 & three-seeded fruit & endotestal & & seed empty \\
\hline S170229 & Famalicão 25 & Taxon 15 & three-seeded fruit & endotestal & embryo preserved, partly & nutritive tissue preserved, partly \\
\hline S170230 & Famalicão 25 & Taxon 15 & four-seeded & endotestal & embryo preserved, partly & \\
\hline S170231 & Famalicão 25 & Taxon 15 & three-seeded fruit & endotestal & & seed empty \\
\hline S170227 & Famalicão 25 & Taxon 16 & three-seeded fruit & endotestal & & nutritive tissue preserved, partly \\
\hline
\end{tabular}




\begin{tabular}{|c|c|c|c|c|c|c|}
\hline S170228 & Famalicão 25 & Taxon 16 & three-seeded fruit & endotestal & & seed empty \\
\hline S171535 & Torres Vedras 43 & Taxon 16 & four-seeded fruit & endotestal & & nutritive tissue preserved, partly \\
\hline S174158 & Famalicão 25 & Taxon 16 & two-seeded fruit & endotestal & & seed empty \\
\hline S174169 & Vale de Agua 408 & Taxon 16 & two-seeded fruit & endotestal & & nutritive tissue preserved, partly \\
\hline S174176 & Vale de Agua 364 & Taxon 16 & two-seeded fruit & endotestal & & seed empty \\
\hline S174360 & Arazede 374 & Taxon 16 & two-seeded fruit & endotestal & & seeds empty \\
\hline S174361 & Arazede 374 & Taxon 16 & one-seeded fruit & endotestal & & seeds empty \\
\hline $\mathrm{S} 174434$ & Famalicão 25 & Taxon 16 & three-seeded fruit & endotestal & & seed empty \\
\hline S174439 & Famalicão 25 & Taxon 16 & three-seeded fruit & endotestal & & seeds empty \\
\hline S174098 & Torres Vedras 38 & Taxon 17 & seed & $?$ & & too compressed \\
\hline S172321 & Catefica 49 & Taxon 18 & one-seeded fruit & seed coat thin & & nutritive tissue preserved, partly \\
\hline S172323 & Catefica 49 & Taxon 18 & one-seeded fruit & seed coat thin & & seed empty \\
\hline S174162 & Catefica 342 & Taxon 18 & one-seeded fruit & seed coat thin & & seed empty \\
\hline S135459 & Vale de Agua 383 & Taxon 19 & two-seeded fruit & seed coat thin & & seeds empty \\
\hline S174163 & Vale de Agua 408 & Taxon 19 & two-seeded fruit & seed coat thin & & nutritive tissue preserved, partly \\
\hline S174172 & Vale de Agua 363 & Taxon 19 & two-seeded fruit & seed coat thin & & nutritive tissue preserved, partly \\
\hline S174173 & Vale de Agua 363 & Taxon 19 & three-seeded fruit & seed coat thin & & seed empty \\
\hline S174436 & Vale de Agua 328 & Taxon 19 & two-seeded fruit & seed coat thin & embryo preserved & nutritive tissue preserved, partly \\
\hline S174037 & Vale de Agua 265 & Taxon 20 & one-seeded fruit & seed coat thin & & nutritive tissue preserved, partly \\
\hline S174314 & Catefica 153 & Taxon 21 & one-seeded fruit & seed coat thin & empty space from embryo & nutritive tissue preserved, partly \\
\hline S174188 & Vale de Agua 363 & Taxon 22 & one-seeded fruit & exotestal & empty space from embryo & nutritive tissue preserved, partly \\
\hline S174362 & Arazede 374 & Taxon 22 & one-seeded fruit & exotestal & & nutritive tissue preserved, partly \\
\hline S174420 & Famalicão 25 & Taxon 22 & one-seeded fruit & exotestal & & seed empty \\
\hline S171515 & Catefica 343 & Taxon 23 & $\begin{array}{l}\text { several-seeded } \\
\text { fruit }\end{array}$ & seed coat thin & & seeds empty \\
\hline S171524 & Catefica 50 & Taxon 23 & $\begin{array}{l}\text { several-seeded } \\
\text { fruit }\end{array}$ & seed coat thin & & seeds empty \\
\hline S172313 & Catefica 49 & Taxon 24 & one-seeded fruit & seed coat thin & & nutritive tissue preserved, partly \\
\hline S172324 & Catefica 49 & Taxon 24 & one-seeded fruit & seed coat thin & & nutritive tissue preserved, partly \\
\hline S172325 & Catefica 49 & Taxon 24 & one-seeded fruit & seed coat thin & & strongly compressed \\
\hline
\end{tabular}




\begin{tabular}{|c|c|c|c|c|c|c|}
\hline S172328 & Buarcos 371 & Taxon 24 & one-seeded fruit & seed coat thin & & nutritive tissue preserved, partly \\
\hline S174186 & Vale de Agua 329 & Taxon 24 & one-seeded fruit & seed coat thin & embryo preserved, partly & nutritive tissue preserved, partly \\
\hline S174419 & Famalicão 25 & Taxon 25 & seed & testal-tegmic? & & seed empty \\
\hline S174190 & Vale de Agua 141 & Taxon 26 & seed & exotestal & & nutritive tissue preserved, partly \\
\hline S170243 & Famalicão 25 & Taxon 27 & seed & exotestal & & seed empty \\
\hline S174426 & Famalicão 25 & Taxon 28 & seed & exotestal & & nutritive tissue preserved, partly \\
\hline S174428 & Famalicão 25 & Taxon 28 & seed & exotestal & & nutritive tissue preserved, partly \\
\hline S174429 & Famalicão 25 & Taxon 28 & seed & exotestal & embryo preserved, partly & nutritive tissue preserved, partly \\
\hline S156205 & Buarcos 157 & Taxon 29 & one-seeded fruit & seed coat thin & & strongly compressed \\
\hline S153503 & Catefica 364 & Taxon 30 & one-seeded fruit & seed coat thin & embryo preserved & nutritive tissue preserved, partly \\
\hline S154531 & Arazede 372 & Taxon 30 & one-seeded fruit & seed coat thin & & nutritive tissue preserved, partly \\
\hline S174115 & Vila Verde 2 & Taxon 30 & one-seeded fruit & seed coat thin & & seed empty \\
\hline S156372 & Buarcos 157 & Taxon 31 & one-seeded fruit & seed coat thin & & strongly compressed \\
\hline S172317 & Catefica 49 & Taxon 32 & seed & exotestal & & seed empty \\
\hline S172319 & Catefica 49 & Taxon 33 & seed & exotestal & & seed empty \\
\hline S174417 & Famalicão 25 & Taxon 34 & seed & exotestal & & strongly compressed \\
\hline S174342 & Famalicão 25 & Taxon 35 & seed & exotestal & & seed empty \\
\hline S174427 & Famalicão 25 & Taxon 36 & one-seeded fruit & seed coat thin & embryo preserved, partly & nutritive tissue preserved, partly \\
\hline S174175 & Vale de Agua 141 & Taxon 37 & seed & seed coat thin & embryo preserved, partly & \\
\hline PP53965 & Puddledock 156 & Taxon 38 & one-seeded fruit & seed coat thin & & seed empty \\
\hline PP53989 & Puddledock 156 & Taxon 38 & one-seeded fruit & seed coat thin & & seed empty \\
\hline PP53990 & Puddledock 156 & Taxon 38 & one-seeded fruit & seed coat thin & & nutritive tissue preserved, partly \\
\hline PP53992 & Puddledock 156 & Taxon 38 & one-seeded fruit & seed coat thin & embryo preserved & \\
\hline PP54037 & Puddledock 156 & Taxon 38 & one-seeded fruit & seed coat thin & & seed empty \\
\hline PP54068 & Puddledock 156 & Taxon 38 & one-seeded fruit & seed coat thin & & seed empty \\
\hline PP54101 & Puddledock 156 & Taxon 38 & one-seeded fruit & seed coat thin & & nutritive tissue preserved, partly \\
\hline PP54102 & Puddledock 156 & Taxon 38 & one-seeded fruit & seed coat thin & embryo preserved, partly & nutritive tissue preserved, partly \\
\hline PP54103 & Puddledock 156 & Taxon 38 & one-seeded fruit & seed coat thin & & seed empty \\
\hline PP54104 & Puddledock 156 & Taxon 38 & one-seeded fruit & seed coat thin & embryo preserved, partly & nutritive tissue preserved, partly \\
\hline PP54105 & Puddledock 156 & Taxon 38 & one-seeded fruit & seed coat thin & & seed empty \\
\hline
\end{tabular}




\begin{tabular}{|c|c|c|c|c|c|c|}
\hline PP54106 & Puddledock 156 & Taxon 38 & one-seeded fruit & seed coat thin & & nutritive tissue preserved, partly \\
\hline PP53952 & Puddledock 151 & Taxon 39 & one-seeded fruit & seed coat thin & embryo preserved & nutritive tissue preserved \\
\hline PP53957 & Puddledock 151 & Taxon 39 & one-seeded fruit & seed coat thin & & seed empty \\
\hline PP53958 & Puddledock 156 & Taxon 39 & one-seeded fruit & seed coat thin & & seed empty \\
\hline PP53959 & Puddledock 156 & Taxon 39 & one-seeded fruit & seed coat thin & & seed empty \\
\hline PP53995 & Puddledock 073 & Taxon 40 & one-seeded fruit & seed coat thin & & nutritive tissue preserved, partly \\
\hline PP53978 & Puddledock 083 & Taxon 41 & one-seeded fruit & seed coat thin & & seed empty \\
\hline PP53964 & Puddledock 156 & Taxon 42 & one-seeded fruit & seed coat thin & & seed empty \\
\hline PP54107 & Puddledock 156 & Taxon 42 & one-seeded fruit & seed coat thin & & nutritive tissue preserved, partly \\
\hline PP54112 & Puddledock 156 & Taxon 42 & one-seeded fruit & seed coat thin & & seed empty \\
\hline PP54111 & Puddledock 156 & Taxon 43 & one-seeded fruit & seed coat thin & empty space from embryo & nutritive tissue preserved, partly \\
\hline PP54153 & Puddledock 185 & Taxon 44 & one-seeded fruit & exotestal & & seed almost empty \\
\hline PP54088 & Kenilworth 174 & Taxon 45 & one-seeded fruit & seed coat thin & & strongly compressed \\
\hline PP54089 & Kenilworth 174 & Taxon 45 & one-seeded fruit & seed coat thin & & strongly compressed \\
\hline PP54090 & Kenilworth 174 & Taxon 45 & one-seeded fruit & seed coat thin & & strongly compressed \\
\hline PP54100 & Kenilworth 061 & Taxon 45 & one-seeded fruit & seed coat thin & & strongly compressed \\
\hline PP53968 & Puddledock 082 & Taxon 46 & one-seeded fruit & seed coat thin & & seed empty \\
\hline PP53969 & Puddledock 082 & Taxon 46 & one-seeded fruit & seed coat thin & & seed empty \\
\hline PP53970 & Puddledock 082 & Taxon 46 & one-seeded fruit & seed coat thin & & nutritive tissue preserved, partly \\
\hline PP54086 & Kenilworth 175 & Taxon 47 & one-seeded fruit & seed coat thin & embryo preserved, partly & nutritive tissue preserved, partly \\
\hline PP54056 & Puddledock 143 & Taxon 48 & two-seeded fruit & seed coat thin & & nutritive tissue preserved, partly \\
\hline PP54048 & Kenilworth 174 & Taxon 49 & one-seeded fruit & seed coat thin & & nutritive tissue preserved \\
\hline PP54022 & Kenilworth 060 & Taxon 50 & one-seeded fruit & seed coat thin & & nutritive tissue preserved, partly \\
\hline PP54025 & Dutch Gap 098 & Taxon 51 & seed & $?$ & & seed empty \\
\hline PP53972 & Puddledock 082 & Taxon 52 & seed & exotestal & embryo preserved, partly & nutritive tissue preserved, partly \\
\hline PP53973 & Puddledock 082 & Taxon 52 & seed & exotestal & embryo preserved & nutritive tissue preserved, partly \\
\hline PP53993 & Puddledock 156 & Taxon 52 & seed & exotestal & empty space from embryo & nutritive tissue preserved, partly \\
\hline PP54039 & Puddledock 156 & Taxon 52 & seed & exotestal & embryo preserved, partly & \\
\hline PP54052 & Kenilworth 174 & Taxon 53 & seed & exotestal & empty space from embryo & nutritive tissue preserved \\
\hline PP54075 & Kenilworth 061 & Taxon 53 & seed & exotestal & & seed empty \\
\hline
\end{tabular}




\begin{tabular}{|c|c|c|c|c|c|c|}
\hline PP54082 & Kenilworth 175 & Taxon 53 & seed & exotestal & empty space from embryo & nutritive tissue preserved \\
\hline PP53999 & Puddledock 073 & Taxon 54 & one-seeded fruit & seed coat thin & & seed empty \\
\hline PP54041 & Puddledock 082 & Taxon 55 & seed & exotestal & empty space from embryo & nutritive tissue preserved, partly \\
\hline PP54035 & Puddledock 156 & Taxon 56 & seed & exotestal & & seed empty \\
\hline PP53974 & Puddledock 082 & Taxon 57 & one-seeded fruit & seed coat thin & & seed empty \\
\hline PP53975 & Puddledock 082 & Taxon 57 & one-seeded fruit & seed coat thin & & seed empty \\
\hline PP53976 & Puddledock 082 & Taxon 57 & one-seeded fruit & seed coat thin & & seed empty \\
\hline PP54110 & Puddledock 156 & Taxon 58 & seed & exotestal & & seed empty \\
\hline PP54062 & Puddledock 151 & Taxon 59 & seed & seed coat thin & embryo preserved, partly & nutritive tissue preserved, partly \\
\hline PP54108 & Puddledock 156 & Taxon 59 & seed & seed coat thin & embryo preserved & nutritive tissue preserved, partly \\
\hline PP54109 & Puddledock 156 & Taxon 59 & seed & seed coat thin & & nutritive tissue preserved, partly \\
\hline PP54073 & Puddledock 156 & Taxon 60 & seed & seed coat thin & embryo preserved, partly & nutritive tissue preserved, partly \\
\hline PP54074 & Puddledock 156 & Taxon 61 & seed & seed coat thin & & nutritive tissue preserved, partly \\
\hline PP54098 & Kenilworth 174 & Taxon 62 & five-seeded fruit & endotestal? & & seed empty \\
\hline PP54038 & Puddledock 156 & Taxon 63 & two-seeded fruit & endotestal? & & seed empty \\
\hline PP54083 & Kenilworth 175 & Taxon 64 & seed & seed coat thin & & seed empty \\
\hline PP54043 & Puddledock 082 & Taxon 65 & two-seeded fruit & exotestal & & nutritive tissue preserved, partly \\
\hline PP54049 & Kenilworth 174 & Taxon 66 & two-seeded fruit & exotestal & & seed empty \\
\hline PP54014 & Kenilworth 061 & Taxon 67 & seed & exotestal & & seed empty \\
\hline
\end{tabular}

